\title{
Degradasi in vitro Fraksi Serat Ransum Berbasis Limbah Jagung Amoniasi
}

\section{In vitro Degradability of Fiber Fraction of Ammoniated Corn Waste Based Ration}

\author{
Elihasridas dan R. W. S. Ningrat \\ Fakultas Peternakan Universitas Andalas \\ email: hasridas21@gmail.com \\ (Diterima: 25 Maret 2015; Disetujui: 22 Mei 2015)
}

\begin{abstract}
ABSTRAK
Tujuan penelitian ini adalah untuk mendapatkan rasio penggunaan limbah jagung amoniasi dan konsentrat dalam ransum komplit ternak ruminansia berdasarkan parameter kecernaan fraksi serat (NDF, ADF, selulosa dan hemiselulosa) secara in vitro. Empat formula ransum komplit adalah; $\mathrm{R} 0=50 \%$ rumput lapangan $+50 \%$ konsentrat (ransum kontrol), $\mathrm{R} 1=40 \%$ limbah jagung amoniasi $+60 \%$ konsentrat, $\mathrm{R} 2=60 \%$ limbah jagung amoniasi $+40 \%$ konsentrat dan $\mathrm{R} 3=80 \%$ limbah jagung amoniasi $+20 \%$ konsentrat. Kecernaan fraksi serat diukur setelah ransum diinkubasi selama 48 jam dengan cairan buffer rumen menurut teknik Tilley dan Terry (1969). Data dianilisis secara statistik menggunakan rancangan acak kelompok, dan perbedaan nilai rataan perlakuan diuji dengan uji Duncan. Hasil yang diperoleh menunjukkan degradasi fraksi serat ransum nyata berbeda $(\mathrm{P}<0.05)$, tetapi R1 dan R0 tidak nyata berbeda. Disimpulkan bahwa rasio $40 \%$ limbah jagung amoniasi dan $60 \%$ konsentrat (R1) menghasilkan degradasi fraksi serat yang lebih baik dari R2 dan R3 dan tidak nyata berbeda dengan ransum kontrol (R0).
\end{abstract}

Kata kunci: in vitro, degradasi, fraksi serat, limbah jagung amoniasi, ransum komplit

\begin{abstract}
The objective of this research was to determine the optimum ratio of ammoniated corn waste and concentrate on the in vitro degradation of fiber fraction. Four treatments complete feed ration consisted of: $R 0=50 \%$ natural grass $+50 \%$ concentrate (control), $R I=40 \%$ ammoniated corn waste $+60 \%$ concentrate, $R 2=60 \%$ ammoniated corn waste $+40 \%$ concentrate and $R 3=80 \%$ ammoniated corn waste $+20 \%$ concentrate. Degradability of fiber fraction measured affter $48 \mathrm{~h}$ incubation with Tilley and Terry technique. Data were analyzed as a block randomized design and differences among treatment means were examined using Duncan multiple range test. The result showed that degradation of fiber fraction significantly affect $(P<0.05)$ each treatment, but $R 1$ and $R 0$ not significantly. In conclusion, ratio $40 \%$ ammoniated corn waste and $60 \%$ concentrate $(R I)$ gave the best result to degradation of fiber fraction and showed the same result with control (RO).
\end{abstract}

Keywords: in vitro, degradation, fiber fraction, ammoniated corn waste, complete feed

\section{PENDAHULUAN}

Limbah pertanian pada umumnya mengandung serat kasar tinggi, protein dan kecernaan rendah, karena komponen terbesar dari serat kasar ini adalah dinding sel (NDF) yang terdiri dari selulosa, hemiselulosa, lignin dan silika. Komponen dinding sel ini merupakan karbohidrat komplek yang meliputi sebagian besar hijauan/pakan serat 
mencapai 40-80\% (Schroeder, 2004). Lignin membentuk ikatan komplek dengan selulosa (lignoselulosa) dan hemiselulosa (lignohemiselulosa) yang sulit dicerna oleh enzim mikroba rumen. Teknologi pengolahan dengan amoniasi urea pada limbah jagung (jerami dan tongkol) cukup efektif meningkatkan kecernaan dan kandungan nitrogennya (Elihasridas et al., 2010).

Kecernaan pakan pada ternak ruminansia tidak hanya ditentukan oleh fermentabilitas pakan, tetapi juga ditentukan oleh enzim mikroba rumen (Elihasridas et al., 2011). Ternak ruminansia mampu memanfaatkan pakan berserat tinggi/ berkualitas rendah karena adanya peran mikroba rumen yang mencerna pakan menjadi nutrien yang siap diserap. Mikroba rumen juga merupakan sumber protein utama bagi hewan induk semang, dimana kontribusi protein mikroba rumen dapat mencapai 60-70 \% dari total asam amino/protein yang diserap oleh ternak (Sniffen dan Robinson, 1987; Russel, 2002), bahkan kontribusi protein mikroba rumen dapat mencapai $100 \%$ pada ternak dengan pakan berbasis hijauan atau limbah pertanian (Firkins, 1996). Keberhasilan memacu pertumbuhan dan kinerja mikroba rumen akan memberikan manfaat besar terhadap peningkatan produktifitas ternak ruminansia (Elihasridas et al., 2011).

Pertumbuhan dan perkembangan mikroba rumen memerlukan ketersedian zatzat makanan esensial seperti karbohidrat mudah larut, protein, sumber nitrogen, dan beberapa mineral (Bach et al., 2005, Puastuti, 2009). Oleh karena itu ketersediaan dan sinkronisasi pelepasan energi dan protein mudah dipakai dalam rumen secara cukup, mutlak diperlukan untuk menunjang pertumbuhan dan produksi protein mikroba yang maksimal. Kebutuhan karbohidrat dan protein mudah larut tersebut dapat disuplai dari konsentrat (Stern and Hoover, 1979; Ginting, 2005; Krehbiel, 2014).

Penggunaan pakan basal berkualitas rendah seperti limbah jagung amoniasi sebagai pakan tunggal tidak akan mampu meningkatkan efisiensi pertumbuhan mikroba rumen. Hal ini disebabkan peningkatan produksi amonia dalam rumen akan cepat terjadi setelah makan, sedangkan pakan yang berkualitas rendah tidak mampu menyediakan energi yang cukup dalam waktu yang singkat untuk keperluan produksi massa mikroba yang maksimal.

Untuk meningkatkan pertumbuhan mikroba rumen dan suplai protein mikroba pada pakan limbah lignoselulosa seperti limbah jagung amoniasi, penambahan konsentrat mutlak diperlukan. Bahan pakan konsentrat sumber energi seperti dedak padi, onggok, jagung, baik untuk diberikan pada ternak sapi yang mengkonsumsi jerami padi amoniasi sebagai hijauan (Hindratiningrum et al., 2011). Peningkatan pertumbuhan mikroba rumen akan berdampak terhadap peningkatan kecernaan fraksi serat ransum. Dengan kata lain, perubahan rasio antara hijauan dan konsentrat dalam ransum akan menentukan efektivitas dan efisiensi sintesis protein mikroba dalam rumen dan sekaligus juga akan mempengaruhi degradasi fraksi serat dalam rumen.

\section{METODE}

Materi yang digunakan dalam penelitian ini: limbah jagung amoniasi (jerami dan tongkol), konsentrat (dedak padi, bungkil inti sawit, onggok, tepung daun ubi kayu, tepung titonia, garam dan lakta mineral), serta medium inkubasi cairan buffer rumen.

\section{Pembuatan Limbah Jagung Amoniasi}

Limbah jagung yang terdiri dari jerami dan tongkol jagung dipotong-potong $3-5 \mathrm{~cm}$, kemudian diaduk merata dengan kotoran ayam kering sebanyak 15\% dari bahan kering limbah jagung. Urea dilarutkan dengan air, dengan perbandingan air yang digunakan dengan bahan kering limbah jagung yang digunakan adalah 1 : 1 . Jumlah urea yang digunakan adalah $4 \%$ dari bahan kering limbah jagung (40 gr urea dilarutkan dalam 1 liter air untuk $1 \mathrm{~kg}$ bahan kering limbah jagung). Limbah jagung dimasukkan ke dalam ember plastik kapasitas 50 lt selapis demi selapis kemudian disemprot dengan larutan urea dan dipadatkan supaya suasana anaerob. 
Tabel 1. Komposisi ransum perlakuan

\begin{tabular}{lcccc}
\hline \multirow{2}{*}{ Bahan pakan $(\%)$} & \multicolumn{4}{c}{ Ransum perlakuan } \\
\cline { 2 - 5 } & $\mathrm{R} 0$ & $\mathrm{R} 1$ & $\mathrm{R} 2$ & $\mathrm{R} 3$ \\
\hline Rumput lapangan & 50 & - & - & - \\
Limbah jagung amoniasi & - & 40 & 60 & 80 \\
Konsentrat & 50 & 60 & 40 & 20 \\
Total & 100 & 100 & 100 & 100 \\
\hline
\end{tabular}

Tabel 2. Komposisi bahan pakan penyusun konsentrat

\begin{tabular}{lc}
\hline Bahan pakan & Proporsi $(\%)$ \\
\hline Dedak padi & 28 \\
Onggok & 20 \\
Bungkil inti sawit & 20 \\
Tepung daun ubi kayu & 15 \\
Tepung daun titonia & 15 \\
Garam & 0,5 \\
Lakta mineral & 1,5 \\
\hline Jumlah & 100 \\
\hline
\end{tabular}

Tabel 3. Komposisi kimia ransum percobaan

\begin{tabular}{lrrrr}
\hline \multirow{2}{*}{ Zat Makanan } & \multicolumn{4}{c}{ Ransum Perlakuan } \\
\cline { 2 - 5 } & $\mathrm{R} 0$ & $\mathrm{R} 1$ & $\mathrm{R} 2$ & $\mathrm{R} 3$ \\
\hline Bahan Kering (BK) & 89,92 & 84,40 & 82,63 & 78,41 \\
Bahan Organik (BO) & 93,84 & 91,55 & 91,23 & 90,14 \\
Protein Kasar (PK) & 13,71 & 13,15 & 12,09 & 11,03 \\
Serat Kasar (SK) & 28,21 & 31,22 & 36,14 & 41,06 \\
Lemak Kasar (LK) & 4,97 & 4,68 & 3,79 & 2,90 \\
T D N & 67,55 & 66,66 & 65,77 & 64,88 \\
BETN & 38,44 & 31,23 & 30,47 & 26,79 \\
Abu & 6,16 & 8,45 & 8,77 & 9,86 \\
N D F & 50,94 & 58,66 & 63,70 & 65,90 \\
A D F & 27,90 & 34,26 & 39,75 & 43,97 \\
Selulosa & 21,72 & 26,16 & 29,76 & 32,03 \\
Hemiselulosa & 23,04 & 24,40 & 23,95 & 21,93 \\
Lignin & 5,30 & 7,19 & 9,04 & 10,95 \\
Silika & 0,88 & 0,91 & 0,95 & 0,99 \\
\hline
\end{tabular}

Sumber: Laboratorium nutrisi ruminansia Fak. Peternakan Unand 2015

Setelah ember terisi penuh lalu ditutup dengan plastik 2 lapis dan diikat dengan tali. Ember disimpan di tempat yang aman dan teduh selama 10 hari. Setelah 10 hari tutup ember dibuka, limbah jagung dikeluarkan dan dikering anginkan selama 2 hari untuk menghilangkan kelebihan gas ammonia, setelah itu dikeringkan dan digiling.

\section{Metode \\ Inkubasi in vitro}

Sampel limbah jagung amoniasi dan konsentrat dikeringkan dalam oven bersuhu $60^{\circ} \mathrm{C}$, kemudian digiling. Sampel kemudian diinkubasi in vitro menurut prosedur Tilley and Terry (1969). Timbang 2,5 g sampel masukkan ke dalam tabung fermentor, kemudian tambahkan $50 \mathrm{ml}$ cairan rumen dan $200 \mathrm{ml}$ larutan buffer McDougall. Setelah itu alirkan gas $\mathrm{CO}^{2}$ lebih kurang 30 detik untuk menjaga kondisi rumen in vitro tetap an aerob. Tutup tabung dengan penutup karet 
berventilasi untuk pengeluaran gas. Kemudian tabung segera dimasukkan kedalam shaker water bath bersuhu $39^{\circ} \mathrm{C}$ selama 48 jam. Setelah inkubasi selama 48 jam, fermentasi dihentikan dengan menambahkan $1 \mathrm{ml} \mathrm{HgCl}_{2}$. Tabung berisi sampel disentrifuse dengan kecepatan 1200 rpm selama 30 menit untuk memisahkan supernatan dan endapan. Selanjutnya endapan digunakan untuk menentukan kandungan fraksi seratnya (NDF, ADF, selulosa dan hemiselulosa) dengan metode Goering, H.K. and P.J. Van Soest (1970).

\section{Rancangan percobaan dan peubah yang diamati}

Rancangan percobaan yang digunakan adalah Rancangan Acak Kelompok (RAK) 4 x 4, dengan 4 macam ransum sebagai perlakuan dan 4 kali ulangan waktu pengambilan cairan rumen sebagai kelompok.

Adapun susunan perlakuan adalah :

Ransum (R0) $=$ Rumput $50 \%+$ Konsentrat $50 \%$

Ransum (R1) = Limbah jagung amoniasi $40 \%$ + Konsentrat $60 \%$

Ransum (R2) = Limbah jagung amoniasi 60\% + Konsentrat $40 \%$

Ransum (R3) = Limbah jagung amoniasi 80\% + Konsentrat $20 \%$

Peubah yang diamati adalah: Kecernaan fraksi serat ransum (NDF, ADF, selulosa dan hemiselulosa).

\section{Analisis Kadar Neutral Detergent Fiber (NDF)}

Timbang 1 gram sampel (a gram) dimasukkan kedalam gelas filter yang telah ditimbang beratnya (b gram). Gelas filter kemudian diletakkan pada Fibertec Hot Extraction Unit dan tambahkan $100 \mathrm{ml}$ larutan NDS (Neutral Detergent Soluble). Selanjutnya tambahkan 2-4 tetes oktanol untuk mencegah terbentuknya busa. Setelah itu dipanaskan (ekstraksi) selama 1 jam dihitung mulai dari mendidih. Hasil ekstraksi disaring, kemudian residu hasil penyaringan dibilas dengan 100 $\mathrm{ml}$ air panas sebanyak 3 kali. Gelas filter yang berisi residu hasil penyaringan dikeluarkan dan diletakkan pada Fibertec Cold Unit dan diisi dengan $25 \mathrm{ml}$ aseton/alkohol $96 \%$ selama
10 menit lalu disaring. Residu dikeringkan dalam oven $105^{\circ} \mathrm{C}$ selama 8 jam. Setelah itu dinginkan di dalam desikator selama 30 menit dan timbang (c gram). Persentase kadar NDF dihitung dengan menggunakan persamaan:

$$
N D F(\%)=\frac{c-b}{a} \times 100 \%
$$

\section{Analisis kadar Acid Detergent Fiber (ADF)}

Timbang 1 gram sampel (a gram) dimasukkan kedalam gelas filter yang telah ditimbang beratnya (b gram). Gelas filter kemudian diletakkan pada Fibertec Hot Extraction Unit dan tambahkan $100 \mathrm{ml}$ larutan ADS (Acid Detergent Soluble). Selanjutnya tambahkan 2-4 tetes oktanol untuk mencegah terbentuknya busa. Setelah itu dipanaskan (ekstraksi) selama 1 jam dibilas dengan 100 $\mathrm{ml}$ air panas sebanyak 3 kali. Gelas filter yang berisi residu hasil penyaringan dikeluarkan dan diletakkan pada Fibertec Cold Unit dan diisi dengan $25 \mathrm{ml}$ aseton/alkohol 96\% selama 10 menit lalu disaring. Residu dikeringkan dalam oven $105^{\circ} \mathrm{C}$ selama 8 jam. Setelah itu dinginkan di dalam desikator selama 30 menit dan timbang (c gram). Persentase kadar NDF dihitung dengan menggunakan persamaan:

$$
A D F(\%)=\frac{c-b}{a} \times 100 \%
$$

\section{Analisis kadar Selulosa}

Analisis kadar selulosa merupakan lanjutan dari analisis ADF. Residu dalam gelas filter direndam dengan $25 \mathrm{ml}$ larutan $\mathrm{H}_{2} \mathrm{SO}_{4}(72 \%)$ selama 3 jam sambil sesekali diaduk. Saring residu dengan bantuan pompa vakum, bilas dengan $100 \mathrm{ml}$ air panas 5 kali dan terakhir dengan $25 \mathrm{ml}$ aseton/alkohol 96\% sebanyak 2 kali. Residu kemudian dikeringkan dalam oven $105^{\circ} \mathrm{C}$ selama 8 jam, setelah itu dinginkan dalam desikator selama 30 menit lalu ditimbang (d gram). Persentase selulosa dihitung dengan rumus:

$$
\begin{aligned}
\text { Selulosa }(\%) & =\frac{c-d}{a} \times 100 \% \\
\text { Hemiselulosa }(\%) & =\% \text { NDF - \% ADF }
\end{aligned}
$$

\section{Analisis Statistik}

Data yang diperoleh dianalisis dengan menggunakan uji keragaman sesuai dengan 
rancangan yang digunakan. Perbedaan nilai rataan tiap perlakuan dibandingkan uji jarak berganda Duncan (DMRT) (Steel and Torrie, 1980). Analisis data dilakukan menggunakan software statistik STATISTICA versi 8.0.

\section{HASIL DAN PEMBAHASAN}

\section{Kecernaan Fraksi Serat Ransum (NDF, ADF, Selulosa dan Hemiselulosa)}

Kecernaan fraksi serat ransum perlakuan dapat dilihat pada Tabel 4. dimana kecernaan fraksi serat ransum perlakuan sangat nyata berbeda $(\mathrm{P}<0,01)$.

Kecernaan fraksi serat ransum R1 (40\% limbah jagung amoniasi $+60 \%$ konsentrat) nyata lebih tinggi dari R2 dan R3 dan tidak berbeda nyata dengan ransum kontrol (R0) $50 \%$ rumput $+50 \%$ konsentrat. Hal ini mengindikasikan bahwa limbah jagung amoniasi dapat digunakan sebanyak $40 \%$ sebagai pakan serat pengganti rumput dalam ransum. Peningkatan proporsi limbah jagung amoniasi dari $40 \%$ (R1) menjadi $60 \%$ (R2) dan $80 \%$ (R3) nyata menurunkan kecernaan fraksi serat ransum. Penurunan ini disebabkan oleh peningkatan kandungan serat kasar, lignin dan silika ransum (Tabel 3).

Kandungan lignin dalam ransum merupakan salah satu faktor yang sangat membatasi kecernaan zat-zat makanan dalam rumen, semakin tinggi lignin dalam ransum maka semakin rendah tingkat kecernaan zatzat makanan ransum tersebut. Lignin kebanyakan berikatan dengan selulosa dan hemiselulosa sehingga selulosa dan hemiselulosa tidak dapat dicerna. Dari komposisi kimia ransum terlihat bahwa kandungan lignin ransum meningkat sangat nyata dari R1 sampai R3. Kecernaan pakan dipengaruhi oleh komposisi kimianya dan fraksi pakan berserat berpengaruh besar terhadap kecernaan zat-zat makanan (McDonald et al. 2002 dan Saili et al., 2007).

Kecernaan NDF, ADF dan selulosa R1 tidak berbeda nyata dengan R0, tetapi kecernaan hemiselulosa R0 nyata lebih tinggi dari R1, R2 dan R3. Hal ini menunjukkan bahwa rumput lapangan mengandung fraksi hemiselulosa atau fraksi serat mudah dicerna lebih tinggi dari limbah jagung. Kecernaan fraksi serat sangat tergantung pada aktifitas mikroba rumen terutama bakteri selulolitik. Aktifitas mikroba yang tinggi membutuhkan ketersedian zat makanan yang cukup terutama energi dan protein. Suplai energi dan protein yang cukup dan seimbang akan mengoptimalkan kondisi fermentasi dalam rumen dan meningkatkan pertumbuhan dan kinerja mikroba rumen sehingga kecernaan pakan meningkat (Krehbiel, 2014).

Bioproses rumen sangat dipengaruhi oleh populasi dan aktifitas mikroba rumen dan fermentabilitas pakan (Oba, $M$ and M.S. Allen. 2003, Elihasridas et al., 2013). Mikroba rumen merupakan ujung tombak pencernaan makanan dalam rumen, semakin tinggi populasi mikroba dalam rumen semakin tinggi pula laju degradasi zat makanan dalam rumen. Laju pertumbuhan mikroba maksimum dapat dicapai apabila pasokan semua nutrient yang diperlukan untuk pertumbuhan dan perkembangan mikroba tersedia dalam konsentrasi optimum terutama suplai energi dan protein (Elihasridas, 2011). Hal ini terlihat menurunnya kecernaan fraksi serat dengan berkurangnya proporsi konsentrat dalam ransum. Menurunnya proporsi konsentrat dalam ransum mengakibatkan berkurangnya

Tabel 4. Rataan kecernaan fraksi serat ransum (NDF, ADF, Selulosa dan Hemiselulosa)

\begin{tabular}{lccccc}
\hline \multirow{2}{*}{ Degradasi (\%) } & \multicolumn{5}{c}{ Ransum Perlakuan } \\
\cline { 2 - 6 } & R0 & R1 & R2 & R3 & SE \\
\hline N D F & $61,51^{\mathrm{a}}$ & $58,47^{\mathrm{a}}$ & $50,98^{\mathrm{b}}$ & $47,64^{\mathrm{b}}$ & 1,24 \\
A D F & $58,72^{\mathrm{a}}$ & $57,16^{\mathrm{a}}$ & $49,83^{\mathrm{b}}$ & $46,12^{\mathrm{b}}$ & 1,36 \\
Selulosa & $59,94^{\mathrm{a}}$ & $58,78^{\mathrm{a}}$ & $51,96^{\mathrm{b}}$ & $48,37^{\mathrm{b}}$ & 0,83 \\
Hemiselulosa & $64,94^{\mathrm{a}}$ & $60,32^{\mathrm{b}}$ & $53,21^{\mathrm{c}}$ & $50,19^{\mathrm{c}}$ & 1,19 \\
\hline
\end{tabular}

Keterangan: Nilai dengan superskrip yang berbeda pada baris yang sama menunjukkan berbeda sangat nyata $(\mathrm{P}<0,01)$.

SE : Standar Error 
suplai zat makanan terutama energi dan protein untuk mikroba rumen sehingga menurunkan populasi dan aktifitas mikroba rumen yang pada akhirnya akan berdampak terhadap kecernaan pakan terutama fraksi serat.

Church and Santos (1981) dan Liu et al., (1988) melaporkan, dimana penambahan konsentrat sebagai sumber protein, karbohidrat dan mineral dapat meningkatkan pemanfaatan jerami padi yang ditandai oleh peningkatan konsumsi dan daya cerna serta pertambahan bobot badan pada ternak ruminansia. Hal yang sama juga dilaporkan oleh Warly (1994), bahwa pemberian bungkil kedelai atau gandum pada domba yang diberi makan jerami padi amoniasi, menghasilkan tingkat fermentasi rumen dan daya cerna zatzat makanan yang lebih tinggi, serta retensi nitrogen dan pertambahan bobot badan yang lebih baik dibanding dengan tanpa pemberian konsentrat. Selanjutnya dinyatakan bahwa dengan pemberian kombinasi gandum (sebagai sumber energi) dan bungkil kedelai (sebagai sumber protein), jerami padi dapat dicerna jauh lebih tinggi dibanding dengan hanya pemberian bungkil kedelai atau gandum saja. Peningkatan ini disebabkan oleh keadaan optimum kondisi rumen yang menunjang aktifitas mikroba rumen sehingga dapat mencerna dengan baik zat-zat makanan ransum yang diberikan.

\section{KESIMPULAN}

Peningkatan proporsi limbah jagung amoniasi dalam ransum menurunkan kecernaan fraksi serat. Rasio $40 \%$ limbah jagung amoniasi dan 60\% konsentrat (R1) dalam ransum komplit menghasilkan kecernaan fraksi serat tertinggi dan tidak berbeda nyata dengan ransum kontrol (R0) $50 \%$ rumput $+50 \%$ konsentrat.

\section{DAFTAR PUSTAKA}

Bach, A., S. Calsamiglia and M.D. Stern. 2005. Nitrogen metabolism in the rumen. J. Dairy Sci., 88 (Suppl.E.):9E21.
Church, D.C. and A. Santos. 1981. Effect of graded levels of soybean meal and nonprotein nitrogen molasses supplement on consumption and digestibility of wheat straw. J. Anim.Sci. 59 : 1609-1615.

Elihasridas, F. Agustin dan Erpomen. 2010. Suplementasi nutrisi terpadu pada ransum berbasis limbah pertanian untuk meningkatkan produktifitas dan kualitas daging ternak ruminansia. Laporan penelitian Hibah Bersaing XVII/I Perguruan Tinggi tahun anggaran 2010.

Elihasridas, F. Agustin dan Erpomen. 2011. Suplementasi nutrisi terpadu pada ransum berbasis limbah pertanian untuk meningkatkan produktifitas dan kualitas daging ternak ruminansia. Laporan penelitian Hibah Bersaing XVII/II Perguruan Tinggi tahun anggaran 2011.

Elihasridas, F. Agustin dan Erpomen. 2013. Perpaduan teknik pengolahan dan optimalisasi bioproses rumen untuk meningkatkan produktifitas dan kualitas daging ternak ruminansia. Laporan penelitian Hibah Bersaing XIX/I Perguruan Tinggi tahun anggaran 2013.

Firkins, J. L. 1996. Maximizing microbial protein synthesis in the rumen. The Journal of Nutrition. 126(4S), 8.

Ginting, S. P. 2005. Sinkronisasi degradasi protein dan energi dalam rumen untuk memaksimalkan produksi protein mikroba. Wartazoa 15 (1).

Goering, H.K. and P.J. Van Soest. 1970. Forage Fiber Analysis. Agriculture Handbook No. $379 . \quad$ United StateDepartment of Agriculture, Washington, DC.

Hindratiningrum, N., M. Bata, dan Suparwi. 2011. Produksi protein mikroba dan neraca nitrogen sapi lokal jantan yang diberi jerami padi amoniasi. Animal Production 11 (2) 116-121.

Krehbiel, C. R. 2014. Invited Review: Applied nutrition of ruminants : Fermentation and digestive physiology. 
Professional Animal Scientist, 30(2) 129-139.

Liu, J.X., M.Okubo and Y. Asahida. 1988. Effects of soybean meal supplementation on fiber digestion in the rumen and voluntary intake of rice straw by sheep. Jpn. Zootech.Sci., 59 (12) : 1034-1039.

McDonald PR, A. Edwards , J.F.D. Greenhalg. 2002. Animal Nutrition 6

th Ed. Longman Scientificand Technical, John Willey and Sons Inc. New York. Hlm 90-95.

Oba, M and M.S. Allen. 2003. Effect of diet fermentability on efficiency of microbial nitrogen production in lactating dairy cows. J. Dairy Sci. 86:195-207.

Puastuti, W. 2009. Manipulasi bioproses dalam rumen untuk meningkatkan penggunaan pakan berserat. Wartazoa. 19. 4: 180-190.

Russel, J.B. 2002. Rumen Microbiology and Its Role in Ruminant Nutrition. NY. Ithaca.

Saily, T., A. Bain, dan L. Nafiu. 2007. Peningkatan pertumbuhan Sapi Bali jantan muda melalui perbaikan manajemen pakan. Jurusan Peternakan,
Fakultas Pertanian Universitas Haluoleo, Kendari.

Schroeder, J.W. 2013. Forage Nutrition for Ruminants. AS1250 (Revised). From www.ag.ndsu.edu

Sniffen, C. J. and P.H. Robinson. 1987. Microbial growth and flow as influenced by dietary manipulations. J. Dairy Sci. 70: 425

Steel, R.G.D. and J.H. Torrie. 1980. Principles and Procedures of Statistics. Mc Graw-Hill Book Co. Inc. New York.

Stern, M.D. and W.H. Hoover. 1979. Methods for determination and factors affecting rumen microbial synthesis : A review. J.Anim. Sci., 49 : 1590-1603.

Tilley, J.M. and R.A. Terry. 1969. A two stage technique for in vitro digestion of forage crops. J. Br. Grssland Soc., 18: 104-111.

Warly, L. 1994. Study on improving nutritive value of rice straw and physic-chemical aspects of its digestion in sheep. Ph.D. Thesis. The United Graduate School of Agriculture Sciences, Tottori University, Japan. 